\title{
PANTA ASTIAZARÁN
}

\section{EN LAS CIUDADES}

Soy un fotógrafo urbano. Me gusta recorrer las calles de ciudades y pueblos fotografiando sus edificios y sus habitantes, estén enfrascados en sus tareas u ociosos. Me gusta descubrir rincones que develan sus misterios sólo ante mis ojos 0 al menos así prefiero creerlo encontrar la belleza oculta en muros olvidados y corroídos por el tiempo.

A veces sueño que estoy en una ciudad muy hermosa y extraña, iluminada por un resplandor crepuscular 0 por esa luz amarillenta que tiñe los recuerdos más viejos. Invariablemente sé que estoy dormido y que cuando pare de soñar la perderé para siempre, porque no recordaré nada de su misteriosa belleza, y entonces me da tanta pena que lloro, y cuando despierto descubro que mis lágrimas han mojado la almohada.

Por eso, cuando estoy despierto, 0 al menos creo estarlo, aprovecho para recorrer las calles de la ciudad en la que me encuentro en ese momento, como un sonámbulo, tratando de rescatar con mi cámara aunque más no sea uno de esos instantes entrevistos. Al acecho de la sorpresa, vago en busca de la ciudad de mis sueños. 

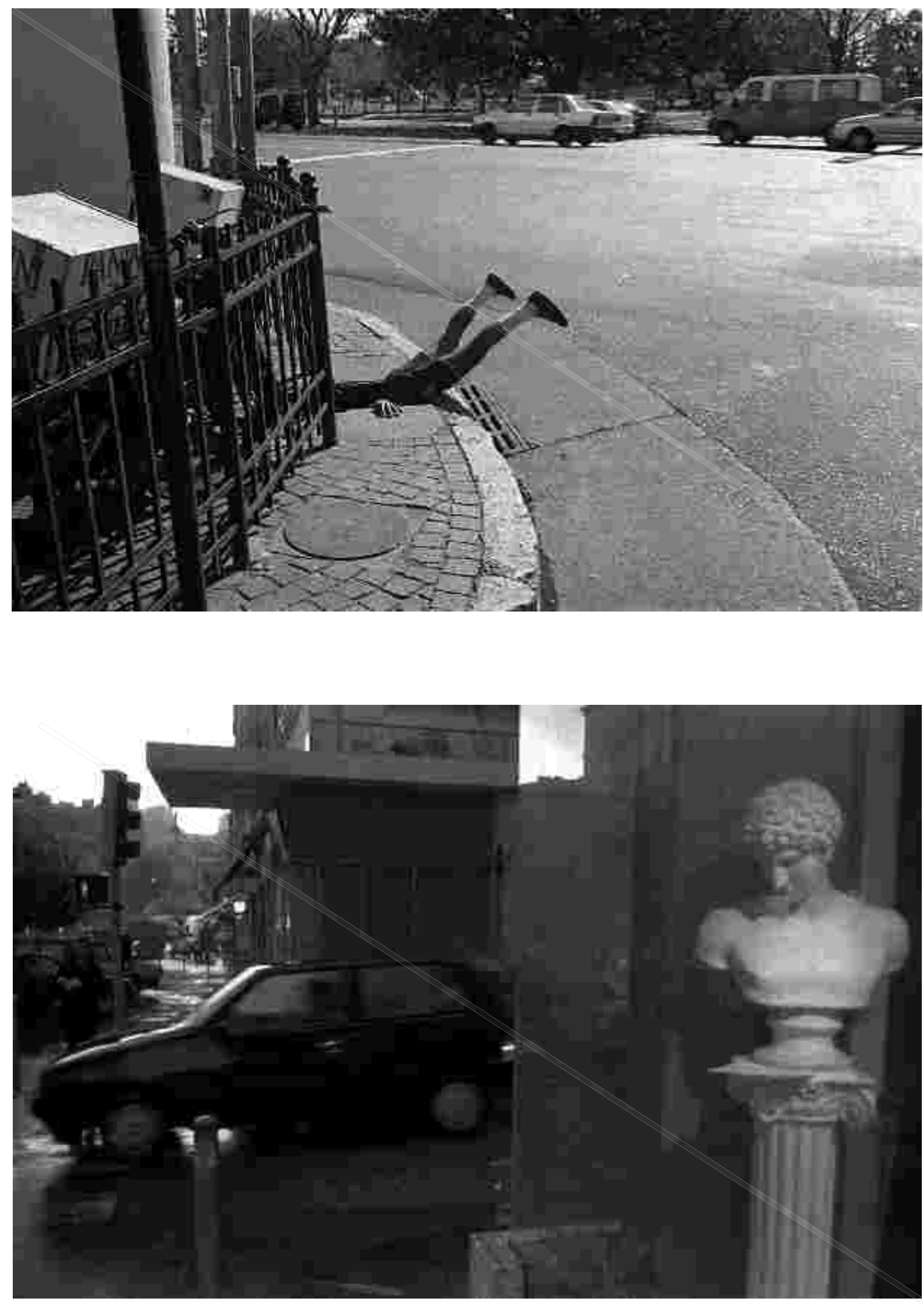

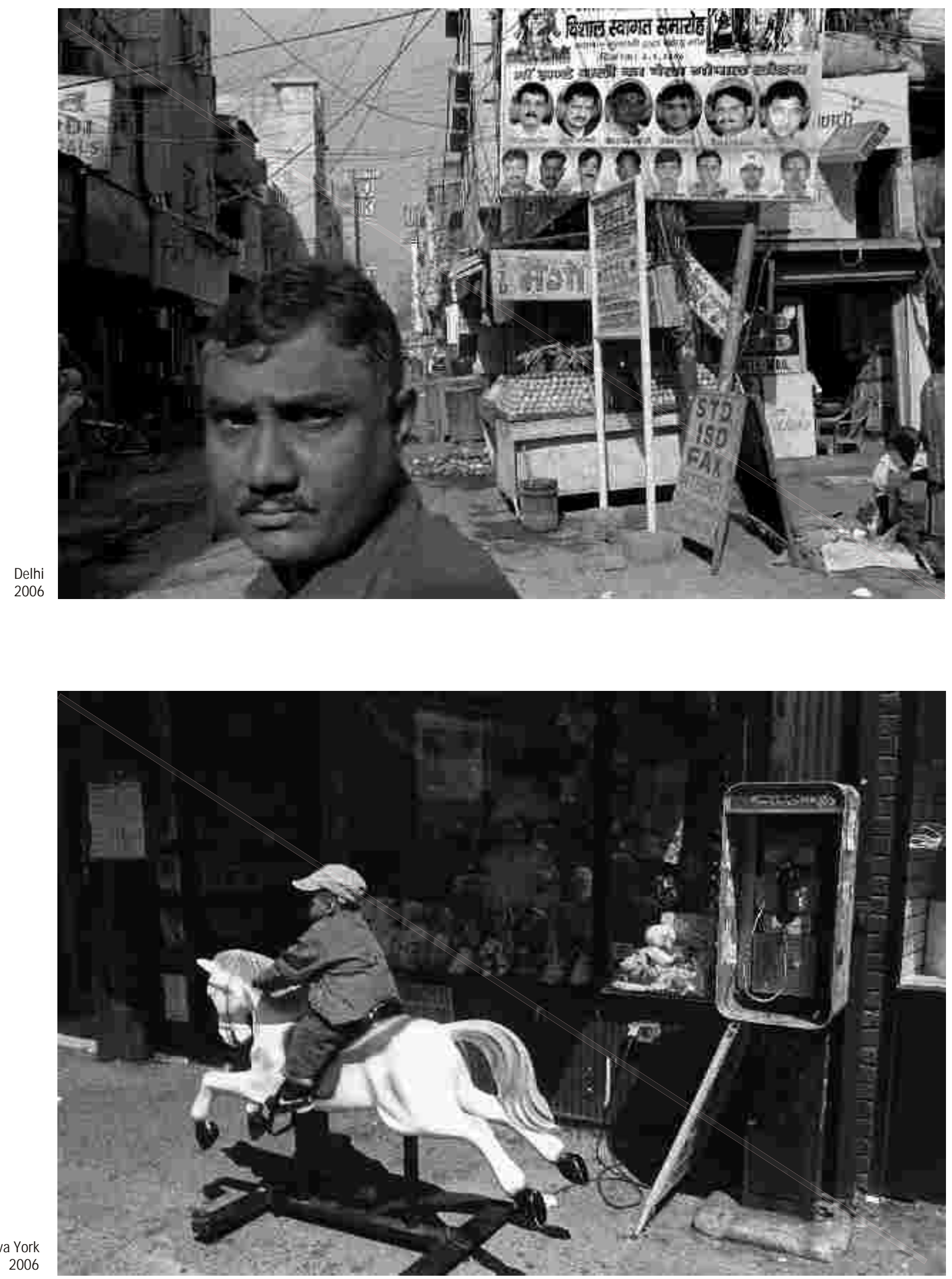